\title{
ХАРАКТЕРИСТИКА ЛІПІНОГО ДИСБАЛАНСУ КРОВІ У ХВОРИХ НА РЕВМАТОЇДНИЙ АРТРИТ НА ТЛІ ХРОНІЧНОЇ ХВОРОБИ НИРОК
}

Вищий державний навчальний заклад України «Буковинський державний медичний університет», м. Чернівці

Резюме. Вивчено вікові та гендерні особливості ліпідного дисбалансу крові хворих на ревматоїдний артрит на тлі хронічної хвороби нирок залежно від вмісту трансформуючого фактора росту-бета. Встановлено, що вираженість дисбалансу ліпідів у хворих на ревматоїдний артрит залежить від стадії ХХН, віку та статі пацієнтів. Вміст трансформуючого фактора росту-бета

Вступ. Ураження нирок при ревматоїдному артриті (РА) підвищує ризик виникнення та прогресування зрушень обміну речовин в організмі, зокрема ліпідного обміну, що у свою чергу, сприяє поглибленню патологічних змін як у нирках, так і в суглобах $[3,5,7,8,16]$.

Сьогодні велика увага приділяється питанню вивчення факторів патогенезу та прогресування як РА, так і хронічної хвороби нирок (ХХН). Дослідження механізмів прогресування поєднаної вищевказаної патології $\epsilon$ надзвичайно актуальною проблемою сьогодення $[1,2,9,10]$. Дисліпідемія є одним із чинників ризику прогресування ХХН. Ліпопротеїди низької щільності (ЛПНЩ) зв'язуються та окиснюються мезангіальними клітинами, що стимулює проліферацію мезангію та розвиток гломерулосклерозу $[13,14,15]$. Крім того, ліпопротеїди, що фільтруються в клубочках, осідають у канальцях та індукують тубулоінтерстиціальні процеси, склероз інтерстицію, що спричиняє прогресування ХХН та розвиток ниркової недостатності. Порушення обміну ліпідів має також величезне значення у прогресуванні РА, що виявляється через порушення процесів мікроциркуляції, перекисного окиснення в вклітинних мембранах та вплив ростових факторів [4, $6,11,12]$.

Мета дослідження. Вивчити вікові та гендерні особливості ліпідного дисбалансу крові хворих на ревматоїдний артрит на тлі хронічної хвороби нирок.

Матеріал і методи. Під спостереженням перебувало 89 хворих на РА віком від 45 до 70 років із тривалістю захворювання 7-10 років, що перебували на лікуванні в нефрологічному та ревматологічному відділеннях ОКЛ м. Чернівці. Всіх пацієнтів розподілено на дві групи: до I групи увійшло 47 хворих на РА з активністю II-III ст. на тлі XXН I ст., до II групи - 42 хворих на РА ст. 3 активністю II-III ст. на тлі XXН II ст. Групу контролю склали 20 практично здорових осіб. Пацієнти у всіх групах були розподілені рівнозначно відносно віку та статі. Всім досліджуваним хворим визначали загальний холестерин (ЗХC), тригліцериди (ТГ), ліпопротеїди високої щільності (ЛПВЩ), ліпопротеїди низької щільності

(С Л.О. Зуб, С.В. Роборчук, М.С. Березова, 2016 відіграє велику роль у прогресуванні ліпідних порушень у хворих на ревматоїдний артрит на тлі хронічної хвороби нирок.

Ключові слова: ревматоїдний артрит, дисліпідемія, трансформуючий фактор росту-бета.

(ЛПНЩ) за загальноприйнятими методиками, трансформуючий фактор росту-бета (ТФР- $\left.\beta_{1}\right)$ плазми крові визначали, використовуючи тестсистеми DRG (США). Критеріями включення в дослідження були: АТ не більше 140/90 мм рт.ст., $3 \mathrm{XC} \geq 5,0$ ммоль/л, ЛПНЩ $\geq 3,0$ ммоль/л; ТГ $>1,77$ ммоль/л; ЛПВЩ $<1,2$ ммоль/л. Статистична обробка отриманих даних здійснювалась із використанням статистичних програм „Excel 5.0” із визначенням середньої величини, стандартних відхилень. Для вірогідності різниці між групами застосовували коефіцієнт Стьюдента (t). Відмінності між групами визнавалися вірогідними за рівня значимості при $\mathrm{p}<0,05$. Проведене дослідження виконано відповідно до етичних норм Гельсінської декларації перегляду 2008 року.

Результати дослідження та їх обговорення. Аналіз клінічно-лабораторних показників всіх обстежених хворих показав порушення ліпідного обміну сироватки крові у вигляді вірогідного збільшення рівнів ЗХС, ТГ і ХС ЛПНЩ на тлі зниження ЛПВЩ порівняно 3 показниками у практично здорових осіб ( $<0,05)$ (табл. 1). Причому найбільш виражений дисбаланс ліпідного обміну виявлено в пацієнтів, що мали РА на тлі ХХН II ст. $(\mathrm{p}<0,05)$.

Необхідно відзначити виражену різницю значень швидкості клубочкової фільтрації (ШКФ) у пацієнтів I та II груп дослідження. Так, якщо у хворих на РА на тлі ХХН I ст. відзначається виражена гіперфільтрація, що є маркером раннього ураження нирок, то у пацієнтів II групи відзначається різке зниження ШКФ. Гіперфільтрація у хворих на РА на тлі ХХН I ст. є дуже цікавим виявленим фактом та потребує подальшого вивчення механізмів ії виникнення (табл. 1).

Гендерний розподіл у групах хворих продемонстрував, що більш виражений ліпідний дисбаланс був у жінок, ніж у чоловіків. Необхідно відзначити, що вагоме підвищення рівня ЛПНЩ спостерігалося як у чоловіків, так і у жінок з РА на тлі XXН II ст. $(\mathrm{p}<0,05)$ (табл. 1).

При дослідженні вмісту ТФР- $\beta_{1}$ крові хворих відзначено також гендерні особливості. Так, у жінок з РА на тлі ХХН показники цього ростового фактора були суттєво нижчими, ніж у чолові- 
Таблиця 1

Характеристика показників ліпідного спектра та вмісту ТФР- $\beta_{1}$ У хворих на ревматоїдний артрит на тлі хронічної хвороби нирок I-II ст. з урахуванням гендерного розподілу $(\mathrm{M} \pm \mathbf{m}, \mathbf{n})$

\begin{tabular}{|c|c|c|c|c|c|c|}
\hline \multirow{2}{*}{ Показники } & \multicolumn{2}{|c|}{$\begin{array}{c}\text { Здорові } \\
(\mathrm{n}=20)\end{array}$} & \multicolumn{2}{|c|}{$\begin{array}{c}\text { I група } \\
(\mathrm{n}=47)\end{array}$} & \multicolumn{2}{|c|}{$\begin{array}{c}\text { II група } \\
\text { (n=42) }\end{array}$} \\
\hline & $\begin{array}{c}\text { Чоловіки } \\
\quad(\mathrm{n}=8)\end{array}$ & $\begin{array}{l}\text { Жінки } \\
(\mathrm{n}=11)\end{array}$ & $\begin{array}{c}\text { Чоловіки } \\
(\mathrm{n}=23)\end{array}$ & $\begin{array}{l}\text { Жінки } \\
(\mathrm{n}=24)\end{array}$ & $\begin{array}{c}\text { Чоловіки } \\
(\mathrm{n}=20)\end{array}$ & $\begin{array}{l}\text { Жінки } \\
(\mathrm{n}=22)\end{array}$ \\
\hline Вік & $56,8 \pm 6,91$ & $57,4 \pm 6,23$ & $57,9 \pm 6,21$ & $56,7 \pm 6,24$ & $58,1 \pm 6,39$ & $58,4 \pm 5,71$ \\
\hline ШКФ, мл/хв & $120,21 \pm 6,91$ & $125,22 \pm 4,81$ & $141,33 \pm 0,24 *$ & $\begin{array}{l}137,92 \\
\pm 4,13^{*}\end{array}$ & $85,34 \pm 9,11 * *$ & $78,91 \pm 9,33 * *$ \\
\hline ЗХС, ммоль/л & $3,3 \pm 0,34$ & $3,8 \pm 0,69$ & $6,23 \pm 0,41^{*}$ & $6,98 \pm 0,72 *$ & $7,15 \pm 0,73 * *$ & $7,25 \pm 0,31 * *$ \\
\hline ТГ, ммоль/л & $1,29 \pm 0,8$ & $1,78 \pm 0,79$ & $2,11 \pm 0,45$ & $2,20 \pm 0,12$ & $2,82 \pm 0,41^{*}$ & $3,9 \pm 0,57 * *$ \\
\hline $\begin{array}{l}\text { ЛПНЩ, } \\
\text { ммоль/л }\end{array}$ & $2,45 \pm 0,8$ & $2,54 \pm 0,65$ & $4,71 \pm 0,21^{*}$ & $4,98 \pm 0,24 *$ & $5,97 \pm 0,23 * *$ & $5,99 \pm 0,44 * *$ \\
\hline $\begin{array}{l}\text { ЛПВЩ, } \\
\text { ммоль/л }\end{array}$ & $1,44 \pm 0,3$ & $1,56 \pm 0,45$ & $1,08 \pm 0,17^{*}$ & $1,03 \pm 0,12 *$ & $0,87 \pm 0,24 *$ & $0,71 \pm 0,05 * *$ \\
\hline $\begin{array}{l}\text { ТФР- } \beta_{1} \\
\text { (пг/мЛ) }\end{array}$ & $56,03 \pm 7,82$ & $55,08 \pm 6,99$ & $99,22 \pm 8,23 *$ & $85,22 \pm 8,23 *$ & $118,81 \pm 8,11 * *$ & $105,84 \pm 6,92 * *$ \\
\hline
\end{tabular}

Примітка. * $\mathrm{p}<0,05$-порівняно з показниками в групі здорових; ** $\mathrm{p}<0,05$ - порівняно з відповідними показниками у хворих I групи

Таблиця 2

Характеристика показників ліпідного спектра та вмісту ТФР- $\beta_{1}$ У хворих на ревматоїдний артрит на тлі хронічної хвороби нирок I-II ст. з урахуванням віку $(\mathrm{M} \pm \mathbf{m}, \mathbf{n})$

\begin{tabular}{|c|c|c|c|c|c|c|c|}
\hline \multirow{2}{*}{ Показники } & $\begin{array}{c}\text { 3рілий вік } \\
(\mathrm{n}=12)\end{array}$ & $\begin{array}{c}\text { Літній вік } \\
(\mathrm{n}=8)\end{array}$ & \multicolumn{2}{|c|}{$\begin{array}{c}\text { 3рілий вік } \\
(\mathrm{n}=69)\end{array}$} & \multicolumn{2}{|c|}{$\begin{array}{c}\text { Літній вік } \\
(\mathrm{n}=20)\end{array}$} \\
\cline { 2 - 7 } & \multicolumn{2}{|c|}{ 3дорові $(\mathrm{n}=20)$} & $\begin{array}{c}\text { I група } \\
(\mathrm{n}=39)\end{array}$ & $\begin{array}{c}\text { II група } \\
(\mathrm{n}=30)\end{array}$ & $\begin{array}{c}\text { I група } \\
(\mathrm{n}=9)\end{array}$ & $\begin{array}{c}\text { II група } \\
(\mathrm{n}=11)\end{array}$ \\
\hline 3ХС, ммоль/л & $3,32 \pm 0,34$ & $3,81 \pm 0,69$ & $6,45 \pm 0,42^{*}$ & $7,19 \pm 0,26^{*}$ & $6,02 \pm 0,65^{*}$ & $6,74 \pm 0,55^{*}$ \\
\hline ТГ, ммоль/л & $1,28 \pm 0,84$ & $1,26 \pm 0,54$ & $2,13 \pm 0,45$ & $3,41 \pm 0,76^{*}$ & $2,46 \pm 0,45^{*}$ & $3,52 \pm 0,37^{*}$ \\
\hline ЛПНЩ, ммоль/л & $2,45 \pm 0,67$ & $2,44 \pm 0,46$ & $2,43 \pm 0,67 *$ & $5,12 \pm 0,76^{*}$ & $4,16 \pm 0,23 * *$ & $5,23 \pm 0,55^{* *}$ \\
\hline ЛПВЩ, ммоль/л & $1,43 \pm 0,74$ & $1,57 \pm 0,43$ & $1,05 \pm 0,67 *$ & $0,72 \pm 0,56^{*}$ & $0,83 \pm 0,44^{* *}$ & $0,51 \pm 0,54 * *$ \\
\hline ТФР- $\beta_{1}$ (пг/мл) & $56,03 \pm 7,72$ & $59,08 \pm 6,91$ & $97,23 \pm 8,13 *$ & $112,22 \pm 7,13^{* *}$ & $102,85 \pm 8,21 *$ & $121,34 \pm 6,72 * *$ \\
\hline
\end{tabular}

Примітка. * p $<0,05$-порівняно з показниками в групі здорових; ** $<<0,05$ - порівняно між віковими групами відповідно до стадій ХХНь

ків як у хворих на ХXН I ст., так і з ХXН II ст. (відповідно $(\mathrm{p}<0,05))$, але порівняно $з$ рівнями даного цитокіну у групі здорових осіб, показники ТФР- $\beta_{1}$ були вірогідно підвищені як у чоловіків, так і в жінок $(\mathrm{p}<0,05)$. Необхідно вказати також на вірогідну різницю показників ТФР- $\beta_{1}$ між групами пацієнтів із XXH I ст. та II ст., що проявилося значним зростанням цього показника у хворих на РА з ХXН II ст. $(\mathrm{p}<0,05)$ (табл.1).

Отримані нами гендерні відмінності досліджуваних показників, на нашу думку, можна пояснити гормональними впливами у жінок протягом усього життя та їх змінами упродовж життя жінки. Тому ризик виникнення різноманітних ускладнень у жінок, навіть при однакових значеннях показників ліпідного спектра 3 чоловіка- ми, може бути нижчий. Однак це потребує ще подальших досліджень.

Проведено характеристику показників ліпідного спектра крові та вмісту ТФР- $\beta_{1}$ хворих на РА на тлі XXН I-II ст. з урахуванням віку (табл. 2).

Згідно з розподілом за віковими категоріями, досліджуваних осіб розподілили на дві вікові групи: I група - пацієнти зрілого віку (45-65 років) та II група - хворі на РА на тлі ХХН літнього віку (старше 65 років, за класифікацією В.Квінна (2000 рік). Отримані дані представлені в таблиці 2.

Аналіз отриманих даних виявив, що показники ліпідного обміну найбільш суттєво відхилялися в осіб літнього віку порівняно 3 пацієнтами похилого віку $(\mathrm{p}<0,05)$ та залежали від стадії ХХН. Так, з дослідження видно, що показники ЗХС крові значно вищі в усіх групах хворих порі- 
вняно з відповідними показниками здорових осіб $(\mathrm{p}<0,05)$ та особливо не відрізняються у пацієнтів 3 XXН I та II стадій (p>0,05).

Така ж тенденція спостерігається з боку показників ТГ крові. А при аналізі показників ЛПНЩ та ЛПВЩ видно, що рівні ЛПНЩ суттєво підвищені не тільки по відношенню до його вмісту у здорових, але й при порівнянні ХХН I з ХХН II ст. Так, у пацієнтів як зрілого, так і літнього віку показники ЛПНЩ суттєво вищі у хворих на PA на тлі XXH II ст. порівняно з відповідними даними хворих на РА з XXН I ст. $(\mathrm{p}<0,05)$ (табл. 2). При дослідженні показників ЛПВЩ відмічалась така ж закономірність, тільки рівні ЛПВЩ були суттєво знижені як у порівнянні з вмістом цього показника у крові здорових $(\mathrm{p}<0,05)$, так i виражені відмінності між групами 3 XXН I та II ст. $(\mathrm{p}<0,05)$.

При дослідженні вмісту ТФР- $\beta_{1}$ у крові хворих відмічено вірогідне його зростання в пацієнтів з XXН II ст. порівняно з I групою досліджуваних $(\mathrm{p}<0,05)$, а також показники ТФР- $\beta_{1}$ були значно вищими в пацієнтів літнього віку порівняно 3 відповідними даними осіб зрілого віку $(\mathrm{p}<0,05)$.

Отже, підвищення рівня просклеротичного фактора ТФР- $\beta_{1}$ крові хворих на РА на тлі ХХН має несприятливе значення при порушенні дисбалансу ліпідів у таких пацієнтів, оскільки може провокувати розвиток грізних ускладнень як 3 боку серцево-судинної системи, так і з боку нирок, поглиблюючи порушення їх функції. Особливо небезпечним та швидким може відбуватися прогресування вищевказаних ускладнень у пацієнтів літнього віку.

\section{Висновки}

1. Встановлено вагомі гендерні відмінності ліпідного дисбалансу у хворих на ревматоїдний артрит на тлі хронічної хвороби нирок I-II ст. 3 його переважанням у жінок.

2. Найбільш виражений ліпідний дисбаланс спостерігався у хворих на на ревматоїдний артрит на тлі хронічної хвороби нирок II ст. літнього віку, що проявляється значним зростанням рівня ліпопротеїдів низької щільності та зниженням вмісту ліпопротеїдів високої щільності.

3. Виявлено зростання рівня трансформуючого фактора росту- $\beta_{1}$ крові хворих на ревматоїдний артрит на тлі хронічної хвороби нирок II ст. літнього віку, що більше проявлялося в чоловіків при проведенні гендерного дослідження.

Перспективи подальших досліджень. У подальшому буде досліджено динаміку ліпідного спектра крові у хворих на ревматоїдний артрит на тлі хронічної хвороби нирок під впливом патогенетичної терапії ревматоїдного артриту.

\section{Література}

1. Батюшин М.М. Клинические проявления и факторы риска поражения почек при ревматоидном артрите / М.М. Батюшин, Е.А. Выставкина // Фундаментальные исследования . - 2012. - № 2. - С. 249-252.

2. Найда В.Т. Порівняльна характеристика показників трансформуючого фактору росту $\beta_{1}$ у хворих на ревматоїдний артрит в залежності від виду патології нирок / В.Т. Найда, Л.О. Зуб, Л.О. Гавриш // Клін. та експерим. патол. - 2011. - № 2 (36), Ч. 2. - С. 72-74.

3. Пат. 85183 Україна, МПК G01N 33/48 (2006.01). Спосіб ранньої діагностики уражень нирок у хворих на ревматоїдний артрит / Зуб Л.О., Кулачек В.Т.; Заявник Буковинський державний медичний університет. № заявки № u201306549 від 27.05.2013; опубл.11.11.2013, бюл. № 21.

4. Ребров А.П. Встречаемость хронической болезни почек и ее структура у больных ревматоидным артритом / А.П. Ребров, Е.В. Волошинова, М.А. Тяпкина // Клин. нефрол. - 2011. - № 6. - С. 32-35.

5. Фоломеева О.М. К проблеме определения внесуставных проявлений ревматоидного артрита / О.М. Фоломеева // Науч.-практ. ревматол. - 2008. - № 2. - С. 74-82.

6. Association of Dyslipidemia with Renal Outcomes in Chronic Kidney Disease / Szu-Chia Chen, Chi-Chih Hung, Mei-Chuan Kuo [et al.] // PLOS ONE. - 2013. Vol. 8, Issue 2. - P. 1114-1116.

7. Afsar B. Dyslipidemias in chronic kidney disease: Current guidelines and future perspectives / B. Afsar // Nephrology. - 2013. - Vol. 1, Issue 1:2. - P. 23-30.

8. Baloch S. Lipid profile in chronic renal disease / S. Baloch, M. Pir, M. Ali [et al.] // IJBPAS. - 2015. Vol. 4 (4). - P. 2000-2006.

9. Kachhawa K. Study of dyslipidemia and antioxidant status in chronic kidney disease patients at a hospital in South East Asia / K. Kachhawa, M. Varma, P. Kachhawa // J. Health Res. Rev. - 2016. - Vol. 3, Issue 1. - P. 28-30.

10. Mannangi N. Novel lipid indices in chronic kidney disease/ N. Mannangi, S. Jayaram, H.S. Viruprakash [et al.] // Natl. J. Med. Res. - 2015. - Vol. 5 (1). - P. 39-42.

11. Dyslipidemia in Patients with Chronic and End-Stage Kidney Disease / Jad Omran, Ashraf Al-Dadah, C.Kevin [et al.] // Cardiorenal Med. - 2013. - Vol. 3. - P. 165-177.

12. Pandya V. Lipid abnormalities in kidney disease and management strategies / V. Pandya, A. Rao, K. Chaudhary // World J. Nephrol. - 2015. - Vol. 4 (1). - P. 83-91.

13. Top-down Lipidomics of Low Density Lipoprotein reveal altered Lipid Profiles in Advanced Chronic Kidney Disease / A. Reis, A. Rudnitskaya, P. Chariyavilaskul [et al.] // J. of lipid research. - 2015. - Vol. 56 (2). - P. 413-422.

14. Samouilidou V. Association of lipid profile with serum PON1 concentration in patients with chronic kidney disease / V. Samouilidou, V. Kostopoulos, A. Liaouri // Ren Fail. - 2016. - Vol.18. - P. 1-6.

15. Szu-chi Chen. Dyslipidemia, Kidney Disease, and Cardiovascular Disease in Diabetic Patients / Szu-chi Chen, Chin-Hsiao Tseng // The Review of diabetic studies. 2013. - Vol. 10, № 2-3. - P. 88-100.

16. Risk factors for chronic kidney disease in Japan: a communitybased study / N. Takamatsu, H. A be, T. Tominaga [et al.] // BMC Nephrol. - 2009. - Vol. 10. - P. 34-44.

\section{ХАРАКТЕРИСТИКА ЛИПИДНОГО ДИСБАЛАНСА КРОВИ У БОЛЬНЫХ РЕВМАТОИДНЫМ АРТРИТОМ НА ФОНЕ ХРОНИЧЕСКОЙ БОЛЕЗНИ ПОЧЕК}

\section{Л.О. Зуб, С.В. Роборчук, М.С. Березова}

Резюме. Изучено возрастные и гендерные особенности липидного дисбаланса крови больных ревматоидным артритом на фоне хронической болезни почек в зависимости от содержания трансформирующего фактора роста- 
бета. Установлено, что выраженность дисбаланса липидов у больных ревматоидным артритом зависит от стадии хронической болезни почек, возраста и пола пациентов. Содержание трансформирующего фактора роста-бета играет большую роль в прогрессировании липидных нарушений у больных ревматоидным артритом на фоне хронической болезни почек.

Ключевые слова: ревматоидный артрит, дислипидемия, трансформирующий фактор роста-бета.

\section{CHARACTERISTICS OF BLOOD LIPID IMBALANCE IN RHEUMATOID ARTHRITIS PATIENTS WITH CONCOMITANT CHRONIC KIDNEY DISEASE}

\section{L.O. Zub, S.V. Roborchuk, M.S. Berezova}

Abstract. It was established age and gender characteristics of blood lipid imbalance in rheumatoid arthritis patients with concomitant chronic kidney disease depending on the content of transforming growth factor-beta. It was estimated, that intensity of lipid imbalance in patients with rheumatoid arthritis depends on the stage of CKD, age and sex of patients. Content of transforming growth factor-beta plays an important role in the progression of lipid disorders in rheumatoid arthritis patients with concomitant chronic kidney disease.

Key words: chronic kidney disease, rheumatoid arthritis, transforming growth factor-beta, lipid imbalance.

Higher State Educational Institution of Ukraine «Bukovinian State Medical University» (Chernivtsi)

Рецензент - проф. О.І. Волошин

(С) Л.О. Зуб, С.В. Роборчук, М.С. Березова, 2016
Buk. Med. Herald. - 2016. - Vol. 20, № 2 (78). - P. 31-34

Надійшла до редакції 05.04.2016 року 